Article

\title{
A Life in Balance: Sattvic Food and the Art of Living Foundation
}

\author{
Stephen Jacobs $D$ \\ Faculty of Arts, University of Wolverhampton, Wolverhampton WV1 1LY, UK; S.Jacobs@wlv.ac.uk; \\ Tel.: +44-(0)1902-323578
}

Received: 26 October 2018; Accepted: 17 December 2018; Published: 21 December 2018

\begin{abstract}
Many modern forms of yoga can be located in the holistic milieu. Discourses of health and wellbeing for mind, body and soul are central in the holistic milieu. Ideas about food and diet are frequently significant aspects of this therapeutic discourse. This paper focuses on ideas about food and diet in the Art of Living Foundation (AOL), a modern transnational yoga movement. AOL legitimises its beliefs about food through an appeal to concepts found in traditional texts on yoga and ayyurveda. In particular, the concept of sattva, which can be translated as balance or harmony-both significant tropes in the holistic milieu-is central to discourses about food choices in AOL and other writers in the holistic milieu.
\end{abstract}

Keywords: Yoga; āyurveda; holistic milieu; therapeutic culture; food and diet; health and wellbeing; The Art of Living Foundation

\section{Introduction}

Sattva: The Ayurvedic Cookbook (Desai 2010) is a recipe book published by the transnational meditation movement The Art of Living Foundation (henceforth AOL). Sattva is a Sanskrit term that is generally translated as balance or harmony. Sattva is a concept more commonly associated with yoga. However, in the modern context sattva is frequently articulated with the ancient Indian medicinal system of ayyurveda in discourses on food and diet. This paper locates AOL in the holistic milieu. The holistic milieu is characterised by discourses and practices that emphasise health and wellbeing for mind, body and spirit. ${ }^{1}$ Balance and harmony are significant tropes in the holistic milieu, and so the concept of sattva seems to be particularly applicable.

In this paper I argue that yoga and āyurveda are significant resources in the holistic milieu and are frequently conflated in many modern forms of yoga such as AOL. Many modern yoga movements, like AOL, advocate a holistic lifestyle. Consequently, modern yoga movements frequently recommend certain foods, patterns of eating and food preparation that are regarded as beneficial for the mind, body and spirit. This holistic foodway is authenticated through reference to traditional sources. The focus of this paper is AOL, but I will also refer to other writers on food in the holistic milieu, such as the Deepak Chopra, to substantiate the argument. AOL also refers to āyurveda in its repertoire of therapeutic practices. However, the āyurvedic ideas and practices advocated by AOL can also be considered as distinctly modern.

Transformations of both āyurveda and yoga can be identified in the modern context, which facilitates an increasing convergence of these two ancient traditions. Dagmar Wujastyk and

1 These discourses and practices are sometimes referred to as The New Age. However, this term is now rather redundant and not widely recognised. As these discourses manifest in a diverse range of amorphous groups-both mainstream and countercultural-and often have little in common other than suggesting an innate interconnection between mind and body, and spirit, I prefer the term holistic milieu. 
Frederick M. Smith (Wujastyk and Smith 2008, p. 2) suggest, 'Modern Ayurveda is characterised by a tendency towards the secularization of ayurvedic knowledge.' De Michelis $(2004,2008)$ makes a cogent case for differentiating modern styles from earlier forms of yoga. De Michelis $(2008$, p. 19) observes that modern yoga, while being derived from aspects of traditional yoga practices and teachings, 'by virtue of export, syncretic assimilation, and subsequent acculturation processes, have by now become an integral part of (primarily) urban cultures worldwide.'

It is important to note that yoga and āyurveda have always been diverse and dynamic and have never been monolithic traditions (see Wujastyk 2003; Mallinson and Singleton 2017). However, for the sake of convenience I will simply refer to traditional yoga, when indicating pre-modern forms of yoga, referencing particular texts where apposite. Many forms of traditional and modern yoga indicate dietary proscriptions and prescriptions. Foodways in traditional forms of yoga and ayyurveda tend to be articulated through complex metaphysical ideas and elaborate conceptions of the body. However, the foodways advocated in modern yoga and ayyurveda tend to selectively use and simplify the ideas found in the classic texts.

The goals of traditional yoga are said to be the acquisition of special powers (siddhis) and/or the attainment of liberation (kaivalya). However, the goal of many modern forms of yoga tends to be expressed in terms of health and wellbeing. This re-articulation of yoga in terms of wellbeing is consistent with what can be termed the therapeutic turn of culture, which Rieff (1966, p. 15) characterises as the release 'from inherited doctrines of therapeutic deprivation; from a predicate of renunciatory control' to a culture 'based on an infinite variety of wants raised to the status of needs.' Yoga, which could be described as a system of 'renunciatory control,' has become transformed into a therapeutic practice. Yoga texts have been appropriated by the therapeutic discourses of many modern forms of yoga to support a lifestyle far removed from the ascetic discipline of the traditional yogi. On the other hand, traditional forms of ayurveda seem to more consistent with the therapeutic ethos of the holistic milieu, as the emphasis tends to be on health and wellbeing and not liberation. Consequently, as the therapeutic aspects of modern yoga practice are emphasised it becomes increasingly implicated with modern āyurveda. This increasing implication is none more obvious than in ideas about food, cooking and eating.

There has always been some commonality between yoga and āyurveda, as they both have somatic and philosophical aspects, and consequently reference the significance of food for physical and spiritual health. Field (2001, p. 37) suggests that āyurveda and yoga are sister sciences as they are both founded in the metaphysical presuppositions of Sāmkhya—one of the six schools, along with Yoga, of Hindu philosophy. Traditionally, āyurveda is more concerned with issues of health whereas yoga is primarily focused on liberation. Frawley (1999, p. 5), an American Hindu also known as Vāmadeva Śāstrī, also suggests that 'Yoga and Ayurveda are sister sciences' and they 'work together to enhance their great benefits on all levels.' The increasing imbrication of these sister traditions is sometimes referred to as 'ayuryoga,' which as Dagmar Wujastyk and Frederick Smith (Wujastyk and Smith 2008, p. 3) indicate is 'becoming a branded commodity in North American spa culture.' Yoga retreats combined with ayyurvedic spas in India and many parts of the world offer packages which include not only āyurvedic massage and yoga lessons, but also emphasise a therapeutic diet. For example, Anānda in the Himalayas provides luxury accommodation, classes in yoga and meditation and a spa 'offering 80 body and beauty treatments, integrating the traditional Indian systems of Ayurveda with the more contemporary Western spa approach.' Food is an important aspect of this luxury ayuryogic spa:

Anānda's wellness cuisine incorporates key principles from Ayurveda, which takes into consideration not just taste, but suitability to body type. Our cuisine is fresh natural foods low in fat and calories with an emphasis on whole grains, fresh fruits and vegetables, lean proteins, low-fat dairy products, and the avoidance of added or artificial salts, colours, flavours, or preservatives. (Anānda in the Himalayas 2018) 
AOL also offers an āyurvedic spa providing a range of therapies. The AOL promotional video ${ }^{2}$ offering 'a holistic wellness experience' looks little different to that offered by Anānda in the Himalayas. It of course also includes 'a multi-cuisine sattvic restaurant [which has] wholesome food with high levels of prana, prepared as recommended by ayurvedic physicians.'

\section{Methodology and Focus}

This paper begins with an analysis of attitudes to food and eating in AOL. As AOL validates its understanding of diet through referencing ancient Hindu ideas and texts, the discussion part of the paper will look at whether AOL's recommendations about food are consistent with traditional texts, such as Patañjali's Yoga Sūtras (PYS), the Hatha Yoga Pradīinikā (HYP) and the Caraka Saṃhitā. My selection of the traditional texts on yoga and ayyurveda cannot possibly represent the diversity of these traditions. Nonetheless, the texts that I have chosen are regarded as significant in both academic and often in non-academic arenas. For example, Wujastyk (2003, p. xxv) suggests, 'the obvious starting point in ayurvedic literature are the compendia of Caraka and Suśruta. These works are absolutely central to ayurveda.' While there is a great deal of debate about the significance of PYS, it has become 'an important reference for many—but by no means all—formulations of yoga' (Mallinson and Singleton 2017, p. xvii).

These traditional texts are compared with modern ideas about yogic and āyurvedic diets, found not only in AOL, but also in contemporary publications. There is a growing market for āyurvedic cookbooks-with titles such as: Eat, Taste, Heal: An Ayurvedic Cookbook for Modern Living (Yarema et al. 2006), The Modern Ayurvedic Cookbook: Healthful Healing, Recipes for Life (Sondhi 2006), Ayurvedic Cooking for Westerners (Morningstar 1995). Many of these cookbooks are simply a manifestation of a growing interest in healthy diets, and either ignore or greatly simplify the complex dietary rules that can be found in the âyurvedic texts.

Again, I have been selective in my choice of modern texts. The main focus of the discussion is on AOL but is also supported by three other contemporary texts on āyurveda and food. First, Deepak Chopra's What Are You Hungry For? (Chopra 2014). Chopra is perhaps the most well-known advocate of modern āyurveda. Zysk (2001, p. 22) observes ‘Chopra has maintained his position as guru or Vaidya Ācārya of New Age Āyurveda in North America and enjoys popularity the world over through his numerous publications.' The subtitle of Chopra's book is The Solution to Permanent Weight Loss, Well-Being and Lightness of Soul, clearly articulating ayyurvedic ideas with the New Age discourses of health and wellbeing. The second text is Maya Tiwari's Ayurveda: A Life of Balance (Tiwari 1995). This book is one of the first and most popular books published on āyurvedic diet. Tiwari's book is also significant as she links her ideas back to the ancient Hindu texts known as the Vedas ${ }^{3}$. Tiwari $(1995$, p. 10) clearly relates ayyurveda to the body, mind, spirit discourse. As well as providing recipes, Tiwari also provides some details of the āyurvedic concepts of the body. Finally, I refer to a more recent book-Ayurveda Cooking for Beginners: An Ayurvedic Cookbook to Balance and Heal — by Laura Plumb, published in 2018 (Plumb 2018).

AOL adopts a body, mind spirit discourse and can be identified as having a therapeutic dimension (see Jacobs 2014). The therapeutic techniques, including yoga and āyurveda, promulgated by AOL are validated through identifying them with Vedic culture. On their website AOL (AOL 2018a) suggests Ayurveda places great importance on one's pathya or lifestyle (eating habits and daily routine). Consequently, AOL serves what they represent as āyurvedic food at all of its centres and on many of their courses. In addition, I will look at Kaushani Desai's book, published by AOL, Sattva: The Ayurvedic Cookbook (2010). Desai, an active member of AOL, has a YouTube channel Healthy Food, Healthy Mind and teaches āyurvedic cookery courses for AOL around the world. This paper

2 Sri Sri Panchakarma available at https: / / www.youtube.com / watch?time_continue=2\&v=HYG9ZDZxxD0.

The Vedas are a vast corpus of compositions. As the Vedas were in origin oral compositions there is a great deal of controversy about their dates. However, most scholars suggest that the earliest parts were probably composed around $1500 \mathrm{BCE}$ and the later parts were probably around 500 BCE (see Witzel 2005). 
is part of a larger ethnographic research project on AOL (Jacobs 2015). Consequently, the textual analysis is supplemented by the ethnographic field work, which included volunteering to help prepare āyurvedic food in the kitchens of the AOL European Headquarters in Bad Antogast in Germany, and the International Headquarters in Bengaluru (Bangalore), more commonly just referred to as the Sri Sri Ravi Shankar Ashram, or simply the Ashram. I also interviewed Kaushani Desai and two other active members of AOL specifically about āyurvedic food.

\section{Sattvic Food and Diet in the Art of Living}

AOL was founded in 1981 by Sri Sri Ravi Shankar-not to be confused with the famous sitar player of the same name. AOL now claims to have a presence in over 150 countries and to have touched the lives of more than 370 million people. Sri Sri Ravi Shankar was associated with Maharishi Mahesh Yogi for a number of years, and Transcendental Meditation is probably the closest relative of AOL. AOL's primary focus is on stress relief. Its central practice is a form of rhythmic breathing technique (prānāyama) that it is claimed was discovered by Sri Sri Ravi Shankar, and which is learned by attending a short course. Those who are drawn into the movement then have the opportunity to participate in various follow-up courses, such as a form of mantra meditation called Sahaj Samadhi, and a form of postural yoga called Sri Sri Yoga (see Jacobs 2015).

At all AOL events and courses as well as in their various ashrams in India and around the world sattvic food is always served. Over the last six or seven years, AOL has included ayyurvedic cookery courses as a part of their programme and has recently introduced Teacher Training Courses in āyurvedic cookery. These courses aim to provide students with the techniques to prepare food properly and diet plans to promote health and wellbeing. The International Headquarters of AOL in Bengaluru has a huge kitchen. During popular festivals like Navrātri there can be as many as 70,000 people to cater for, and on an average day there can be over 1000 people staying on the Ashram. On the main AOL ashram in Bengaluru 'the food is Sattvic (food that induces a calm mind) and is cooked using steam produced from environmentally-friendly boilers using briquettes (a type of fuel that is made from a mixture of sawdust, groundnut and coffee shells)' (AOL 2018b). This clearly articulates food preparation with both therapeutic and environmental concerns. Desai suggests that sattvic foods are 'light for digestion' and 'lead to harmony and balance between body and mind' (personal interview, April 2014). An AOL teacher indicated that it is necessary to serve sattvic food on the courses in order to fully benefit from the yoga and breathing techniques (personal interview, April 2014). Sattvic food is represented as 'high energy vegetarian food' (AOL 2015a).

While sattva is a complex concept found in yoga philosophy, this is not the place to go through the involved metaphysical conceptions of yoga (see Whicher 1998). It is sufficient to say that yoga metaphysics posits two fundamental eternal and ontological categories: consciousness (puruṣa) and matter (prakrti). Matter (prakrti) has three qualities known as the gunas: sattva, which means balance, harmony, light; rajas, which means action, energy passion; and tamas which has connotations of darkness and inertia. All of creation, which includes food, can be categorised according to which of these qualities predominates. According to AOL (2018c), sattvic foods include fresh fruit and vegetables; rajasic foods include ready to eat meals, garlic and onions; and tamasic foods include alcohol, tea, coffee, meat and fried foods. While it is indicated that food should not be too spicy or salty, certain spices such as turmeric, cardamom and cinnamon are regarded as sattvic. It is important to note that this list of foods does not necessarily correspond to classification of food outlined in either the classical texts on yoga and āyurveda or even other modern versions of āyurvedic diets.

In the primordial state these three qualities—sattva, rajas and tamas-are held in perfect balance. However, according to yoga philosophy, when this equilibrium is disturbed, through the entanglement of consciousness with matter the process of creation, or more accurately the manifestation of the cosmos, takes place. The manifestation of the cosmos moves from subtle to more gross levels of being. It is important to state here that mind is categorised as matter (prakrti) and not consciousness (purusa) — consequently mind, along with all of creation, also has these three qualities. The relative 
dominance of each of these qualities has a direct impact on our state of mind. Eliade (1989, p. 23), paraphrasing PYS states:

When sattva predominates, consciousness [mind] is calm clear, comprehensible, virtuous; dominated by rajas, it is agitated, uncertain, unstable; overwhelmed by tamas, it is dark confused, passionate, bestial.

Sri Sri Ravi Shankar (2012) in an interview about food observes that:

Rajasic food creates restlessness in the body and too many desires and ambitions come out. Then you go yo-yo-either you become very happy or you go right down. Sattvic food brings equanimity, happiness, creativity, a sense of serenity and calmness (sic). (Sri Sri Ravi Shankar 2012)

In this view there is a direct correlation between what you eat and your state of consciousness. Sri Sri Ravi Shankar also alludes to the idea that a sattvic diet is one that is conducive to a balanced and harmonious life.

Many active participants in AOL understand the different qualities of food in terms of prāna-the subtle energy that pervades the body. Sattvic food is considered to raise the level of pranna. The concept of a subtle energy that has a direct impact on health and wellbeing is another common trope in the holistic milieu-found not only in the discourses of modern yoga, but also other therapeutic practices such as Tai Chi and Reiki.

One long-term active participant in AOL suggested:

Tamasic is any food that brings the prāna down-makes you less focused, less sharp less energised. Rajasic food causes energy to manifest as nervousness, aggression and bullishness. Sattvic foods maintain a balance that is beneficial to the body and the mind. (personal interview, March 2014)

This idea of prāna is also linked to the imperative to eat food as fresh as possible. Sri Sri Ravi Shankar (2012) states that 'sattvic food is cooked and eaten immediately_fresh,' but if it is left for $8 \mathrm{~h}$ it becomes rajasic, and eventually tamasic. Microwaving food and frying also renders it tamasic. In other words, it is considered that prāna can degenerate overtime or when using certain methods of food preparation. This can have a detrimental effect on the quality of the food, which in turn can have a negative impact on one's practice of yoga and meditation and be harmful to the mind, body and spirit. Chopra (2014, p. 89), also indicates that 'the fresher the food, the more life force, or prana is available.' Consequently, Chopra recommends avoiding what he calls FLUNC foods-frozen, leftover, unnatural, nuked and canned foods.

\section{Vegetarianism, Science and the Vedic Tradition}

Meat is normally classified as being either rajasic or tamasic, and therefore to be avoided. Vegetarianism is an important aspect of AOL foodways and modern ayyurvedic diets. When one participates in the introductory AOL course-the Happiness Program, which unlike the advanced courses is not residential-there is no mention of terms like sattva or āyurveda. Nonetheless, participants are recommended to avoid tea and coffee-regarded as stimulants and therefore classified as rajasic - and try and maintain a vegetarian diet during the four days of the course. The food on the ashrams and served on residential courses is always vegetarian. In a talk on vegetarianism Sri Sri Ravi Shankar suggested:

If you want to be more sensitive and more sharp and have deeper experiences it is very important not to eat meat. Meat is very gross. It can produce grossness in the body but not subtlety in the mind. (Sri Sri Ravi Shankar 1992) 
This is a reference to yogic ideas about the relative subtlety of states of mind and that what we consume can have a direct impact on our body and mind. Sri Sri Ravi Shankar (1992) dismisses the idea that meat can give your strength-'a horse just eats grass and grain, yet we say horsepower, it is more strong' (sic).

Vegetarianism is also represented as a moral choice. Sri Sri Ravi Shankar (1992) argues 'from a moral point of view, ethics, we have no right to destroy any animal, take any life on this planet.' The moral dimension of a vegetarian diet is frequently articulated in terms of ahimis $\bar{a}$ (non-violence), which is an important concept in many forms of modern yoga, and is validated by reference to PYS.

When we think about Hinduism and food, the first thing that springs to most people's minds is that Hindus are vegetarian. Although this does apply to many Hindus, it is not universal. In the Vedic period meat was eaten and the Caraka Sam hit $\bar{a}$ certainly does not prescribe a vegetarian diet. The Caraka Samhitā mostly indicates that no particular food type should be taken in excess and recommends various types of food for particular physiological benefits (see Van Loon 2002, pp. 236-44). It lists a whole range of meats, including camel, cow (beef) as contributing to alleviating certain ailments, such as chronic piles, and are 'useful for people who exercise regularly and have strong digestive powers.' Tiwari $(1995$, p. 179) is clearly aware that the traditional texts on āyurveda do not necessarily prescribe a vegetarian diet. She suggests that eating some meat was appropriate in the past in societies that hunted, and 'early humans pursued the chase not only to feed themselves but also to discover their full potential.' However, Tiwari argues that in contemporary societies meat is no longer required and 'we no longer have to hunt or to kill in order to recognize our nature.'

It is probably around the time of the Buddha, that vegetarianism became a significant aspect of Hindu foodways, and in particular as a signifier of high caste. The Emperor Ashoka in the third century $\mathrm{BCE}$, who converted to Buddhism, was largely responsible for popularising a vegetarian diet. By the time that Babur invaded India in the early sixteenth century 'vegetarianism had become a powerful statement of one's position in Indian society' (Collingham 2005, p. 21). Vegetarianism is also becoming increasing popular in the developed world. ${ }^{4}$ While vegetarianism is not universally adopted, it is overwhelmingly the diet of choice in the holistic milieu, as a non-meat diet is considered conducive to health and wellbeing of the body, mind and spirit.

Vegetarianism is often considered as critical in yoga, and in particular modern forms of yoga. Recipes in all three yoga magazines in the UK-Om Yoga, Yoga Magazine and Yoga Journal—and the vast majority of āyurvedic cookery books are exclusively vegetarian or vegan. These recipes and articles on food suggest that a vegetarian or vegan diet is primarily a lifestyle and health issue. However, in yoga circles the argument for a vegetarian diet is also often linked to the idea of ahimins -non-violence. In Steven Rosen's edited book Food for the Soul: Vegetarianism and Yoga Traditions (Rosen 2011) every contributor makes a reference to ahimins, and virtually all refer to PYS.

Sri Sri Ravi Shankar substantiates his view on vegetarianism through a quasi-scientific argument. Sri Sri Ravi Shankar (1992) argues that when an animal is slaughtered it dies in an anxious state of mind. This anxiety, he suggests, produces a chemical, which when it is ingested produces anxiety in the eater. In his talk, he suggests that the length of the digestive tract and shape of teeth indicates that humans are biologically best suited to a vegetarian diet. The idea that practices are 'scientific' is a very common trope in modern yoga. ${ }^{5} \mathrm{He}$ argues that meat eating is a cultural habit, and not a biological necessity. He suggests that if you have a vegetarian diet: 'You will not get cancer, you will not get many mental problems [such as] depression. Most of the problems of human kind today are related to the type of food that we eat.' Here, Sri Sri Ravi Shankar alludes to the idea that there is a direct correlation between individual wellbeing and the state of the world encapsulated in AOL's aspiration to create 'a stress free, violence free society.' In other words, there is a direct connection between an

4 The BBC reported in February 2018 that 'a quarter of UK dinners have no meat or fish' (BBC 2018).

5 This can be traced back to people like Swami Kuvalayanda, who from the mid-1920s sought to demystify yoga through science by measuring various physiological changes when doing yoga and meditation (Alter 2004, p. 82). 
individual's diet, state of mind and societal conflicts. Poor diet, in this instance a non-vegetarian, and therefore non-sattvic diet, creates stress and anxiety in the individual, which is considered to be a direct cause of social and global issues.

While a quasi-scientific rationale is important in validating a vegetarian and sattvic diet in AOL discourses, many in the so called 'baby-boomer' and subsequent generations are ambivalent about the ability of science to solve the problems of humanity. Science is represented in the holistic milieu as failing to address basic spiritual needs. While nutrition, as a science, can inform us about the physical aspects of diet, it neglects other important aspects of our being. Food should be nutrition for body, mind and soul. Furthermore, nutrition as a science has contributed to the industrialisation of food production, which is often blamed for issues such as the rise of obesity. Consequently, it is suggested that one can find wisdom, including knowledge of correct diet, in ancient traditions. Reference to the ancient Vedic roots authenticates and legitimises the AOL ideas about food and diet. The ancient Vedic ideas about food are represented as the panacea for the now well documented problems of fast, processed, high fat, high sugar modern diets.

While āyurveda as a systematic medical theory and practice can only be identified from the Buddhist period in the fifth century BCE (see Wujastyk 2003; Wujastyk and Smith 2008), its authenticity is validated by tracing its roots to the Vedas.

The knowledge of Ayurveda was passed on orally through a lineage of sages in India until it was collated into text more than five thousand years ago. The oldest known texts on Ayurveda are the Charaka Samhita, Sushruta Samhita, and the Ashtanga Hrudaya. (AOL 2018d)

Desai indicated that 'âyurveda is more than 5000 years old' and should be considered as the fifth Veda. Traditionally there are said to be four Vedas— $R g$, Yajur, Sāma and Atharva-which are regarded as having been directly revealed to the ancient sages. In other words, it is believed that the knowledge found in the Vedas is not of human, but divine, origin. Desai suggested that āyurveda 'comes straight from God's mouth' (personal interview, April 2014). Similarly, Tiwari (1995, p. 8) suggests, 'Ayurveda is rooted in India's most cherished scriptures known as the Vedas.' Wujastyk (2003, p. xxix) notes that while both Caraka and Suśruta 'claim descent from the Veda ... for the most part they do not form any obvious precursor to the system of classical ayurveda.' What is significant is that reference to the continuity with the Vedic past legitimises the ideas. The assertion that the ideas about food and diet can be traced back to the Vedas implies that Desai's and Tiwari's views on food and diet are authentic, as they are rooted in an ancient tradition.

However, traditions are often dismissed as irrational superstitions. Consequently, it is important to show that in fact the ancient yogic tradition, if properly understood, is both rational and at the same time avoids the dangers of an exclusive reliance on a scientific paradigm. In an AOL promotional video entitled Meditation-Then and $N o w^{6}$, the ancient $r s ̦ i s$ or Vedic seers are represented as some of 'the world's first scientists,' who by meditating 'were able to discover amazing secrets about the human body mind and consciousness, such as what you eat affects what you think.' Tradition and rationality mutually reinforce each other and therefore the validity of what is being claimed. AOL (2015b) identifies āyurveda as 'an ancient science for the modern lifestyle.'

Desai as well as indicating the sacred origins of an āyurvedic diet also emphasised that the principles of āyurveda are scientific and rational. This emphasis on rationality facilitates the claim that an āyurvedic diet is not restricted to India, but is globally apposite. Desai now travels the world teaching āyurvedic cookery and adapts the principles to local cuisines. When I interviewed Desai (via Skype) she was in Italy and she indicated:

6 Available at https://www.youtube.com/watch?v=xRMf4z8Cs8s. 
I am not teaching them Indian food ... I select the local products from the market-vegetables, grains, pulses and spices—and then I create recipes that are sattvic ... [participants] can create sattvic recipes-Italian, Mexican, African it does not matter. Âyurveda is not limited to just Indian cuisine. After coming to Italy, I made pesto, because pesto is very important for the Italian diet. So, we made pesto without oil. (Personal interview, April 2014)

Sattvic foods according to Desai are those that create a harmony and balance between body and mind. Sattvic foods are not only about the ingredients, but also about the cooking method. Frying is regarded as non-sattvic and almost no oil is used in AOL cuisine, hence Desai's omission of oil to make a sattvic version of pesto. Steaming is the main method of cooking in the AOL kitchens at Bad Antogast and Bengaluru. Desai maintains that steaming and baking are the preferred methods in sattvic cooking. In her book Sattva, most recipes use no oil or fats whatsoever, at most the occasional recipe utilises a teaspoon of oil or ghee. However, this preference for steaming and avoidance of frying and fats is not universal. Tiwari (1995, p. 258) and Plumb (2018, p.175), for example, both use oil in their recipes for pesto. However, Tiwari states that 'oils should not be used excessively,' and overall uses very little oil in her recipes, and none of her dishes are deep fried. Morningstar (1995, p. 15) classifies fried food as tamasic, and Plumb (2018, p.30) suggests that fried food is rajasic and can disrupt digestion (Plumb 2018, p.35).

\section{The Cook and the Eater}

One of the clearest links between food and the gunas can be found in the important Hindu text the Bhagavad Gìtä:

The foods preferred by the pure increase life-span wellbeing, strength, health, ease and pleasure; they are flavoursome, mild, firm textured and easy to swallow.

Foods desired by the passionate are pungent, bitter, salty, very hot, sharp, dry and burning, they cause pain anguish and sickness.

People of darkness prefer food that is raw, tasteless, putrid, left to stand overnight, leavings, and food rejected for sacrifice. (Bhagavad Gìtā 17: 8-10 in Johnson 1994, p. 71)

These verses suggest that it is the quality of the person which determines what sorts of food they find appealing. In other words, sattvic people prefer certain types of foods. However, also implicit in this is the idea that food can also be classified according to its qualities-so 'flavoursome, mild, firm textured and easy to swallow' foods are sattvic. It is only a short step to concluding that the quality of food that one consumes will have a direct impact on the quality of consciousness. The opening line seems to suggest therapeutic benefits to a sattvic diet. However, if a diet is constituted of predominantly 'pungent, bitter and salty' foods, it will stimulate restlessness (rajas) in the mind of the eater, and if food is stale it will induce inertia (tamas) in the eater.

While food can be classified according to whether it is sattvic, rajasic or tamasic, the quality of the food can deteriorate if poorly prepared or stale. There are also a number of other considerations, such as the state of mind of the cook and the eater, and the context of producing and consuming food which can have a direct impact on the nature of the dishes. Desai indicated:

If we are sad or angry when we cook food, then we will spoil the energy of the food. We should be happy when we prepare food. We should cook with a lot of love. These things will have an impact on the food. (Personal interview, April 2014)

This is a very common idea linked to the concept of vibration, another popular trope in the holistic milieu. This idea suggests that our emotions have a particular vibration, and this vibration can have a direct impact on our environment. If the cook is in a sattvic state of mind when he/she prepares food, this can increase the sattvic quality of the food, through the harmonious vibrations that 
are emanated. When asked by the interviewer how the cook can ensure that they are in a positive frame of mind when preparing the food Sri Sri Ravi Shankar (Sri Sri Ravi Shankar 2012) suggested 'that is down to prānāyama. ${ }^{7}$ People who do prānāyama every day, morning and evening, will raise their prāna.' He further suggests that the enjoyer of food can also contribute to the wellbeing of the producer by reciting the Sanskrit prayer 'annandata sukhi bhava-let the giver of food be happy.' Sri Sri Ravi Shankar includes both the farmer and merchant, as well as the cook in his definition of producer. Sri Sri Ravi Shankar (Sri Sri Ravi Shankar 2012) continues that: 'You cannot cleanse the vibration of the whole world, but at least you can wish happiness for others. By wishing like that you create a very positive atmosphere around you.'

In most AOL centres after the food has been prepared and before it is served it is blessed by chanting mantras by all those who had been involved in the preparation and cooking. A verse (chapter 4: verse 24) from the Bhagavad Gita is frequently chanted. This is translated by Desai (2010, p. 18) as follows:

The act of offering is Brahma (God)

The oblation is Brahma (God)

By Brahma (God) it is offered into the fire of Brahma (God)

Brahma (God) is That which is to be attained by him who sees Brahma (God) in all.

In other words, the person who offers food (the cook) is sacred, the food itself is sacred, and the eater is also regarded as sacred. The understanding that God is in the cook, the food and the eater leads to a realisation of the inherent interconnectedness and sacredness of everything. Desai (personal interview, 2014) suggests that this blessing transforms food into prasād, which more or less means 'grace.' In Sanskrit the term bhoga means 'enjoyment, pleasure' and is used to indicate food. When food is offered to a deity it becomes transformed from something that is merely pleasurable into something that is sacred. ${ }^{8}$ However, it is not only the food that is transformed, but also our attitude to eating. Desai in her cookbook (Desai 2010, p. 19) suggests:

The very act of offering the food to God and then eating it as prasad changes the entire attitude towards the food and how food is eaten. There are no complaints or criticism about the quality of food and it is eaten with reverence and acceptance. This attitude has a great impact on the digestion of the food.

The sattvic qualities of the food can therefore be enhanced by chanting. Desai (personal interview, 2014) explained that 'chanting before the food is served cleans the energy of the food.' Once again, a spiritual idea is validated through a claim to quasi-scientific ideas about energy. When the eater consumes sattvic food, the mind becomes increasingly sattvic in nature. Consequently, food can be seen as a conduit between the state of mind of the person who prepares the food and the state of mind of the eater. If the cook is in an agitated state, this will increase the rajasic quality of the food, and consequently provoke the rajasic quality of mind in the eater, who will then feel agitated.

Desai (personal interview, April 2014) also explains that if you chant before eating it sends a signal to the stomach and 'the stomach will be prepared to accept the food and digestion will be better.' This idea is consistent with what Guy Beck (1993) has termed a 'sonic theology.' Chanting Sanskrit mantras is regarded as transforming both the food and the body. This idea is frequently articulated in terms of vibration. The vibrations created through chanting are thought to bring harmony and balance to all aspects of food preparation and consumption.

7 This is clearly a reference to sudarshan kriya - a rhythmic breathing technique (or form of prānāyama) which is the core practice of AOL.

8 The idea of transforming food by offering it to the deity is of particular significance in the International Society for Krishna Consciousness (ISKCON). 'We sanctify the food, offering it to God, which is called prasadam, meaning the mercy of the Lord. This sattvic (goodness) diet, which refrains from meat, eggs, alcohol, caffeine is most conducive for spiritual growth' (ISKCON 2014). 
This idea is reinforced when Desai suggests that the environment in which food is prepared is also significant. She suggested that if food is cooked in a tamasic environment even though it is sattvic it will become tamasic. The mind-set of the cooks also has a direct impact on the environment of the kitchen, and by extension will influence the quality of the food. In the short video about the Bengaluru kitchen it suggests 'not only is physical cleanliness is important in the kitchen, but a lot of emphasis is given to purity of mind as well' (AOL 2015a). Certainly, from my experiences of the kitchens at both Bengaluru and Bad Antogast, despite having to produce vast amounts of food, they are very clean, calm and organised environments. ${ }^{9}$

Āyurveda also recognises that different people have different constitutions, and therefore might require different diets. According to āyurvedic physiology there are three bodily humours (dosas) — these are vāta (wind/air), pitta (gall/fire) and kapha (phlegm/earth). These are all present in the body, the relative proportions of these principles determine our physiological and psychological constitution. ${ }^{10}$ When these three principles are in equilibrium we will be in good health, and disease is caused by an imbalance of these principles. However, naturally there tends to be a dominance of one or two of these principles, and this determines our constitution. Diet aids balancing the three humours. Consequently, it is important to ensure that what one eats will maintain an equilibrium of the doṣas for your particular body type.

A long-time participant of AOL suggested that:

Some foods suit certain types of people. Āyurveda splits people into three types-kapha which is the earth element, vatta which is the air element and pitta which is the fire element. So, I have been diagnosed as pitta with kapha, which makes sense to me-a fiery personality with some vāta quality of flightiness, airy. Yet my husband is kapha-more deliberate and calmer. [Theoretically] I should cook different menus for him and me. (Personal interview, April 2014)

Although there is only a brief mention of the doșas in Desai (2010), both Tiwari (1995, pp. 43-56) and Plumb (2018, pp. 8-9) provide some explanation of these convoluted ideas about the bodily types and the humours found in the classical texts, such as the Caraka Samhitā. Tiwari describes the various characteristics of each body type such as body shape, hair colour and condition, appetite, sleeping patterns and so on. Tiwari produces charts for all these body types indicating: Major foods that should be eaten regularly; minor foods that should be eaten occasionally; and regressive foods which should be avoided. For example, Tiwari suggests that bell peppers should be avoided by those with vāta body types, but they are a major food for those with a pitta body type. Each recipe in the back of the book is coded according to which body types the particular dish is appropriate for. For example, Tiwari (1995, p. 283) indicates that her recipe for millet and corn soup is appropriate for kapha, kapha-vāta and kapha-pitta types. The suggestion that there is no universal prescription for a healthy diet, and that one has to take everybody's personal constitution into account when determining the healthiest diet, is consistent with the emphasis on individualism in the holistic milieu.

\section{Modern Āyurveda, Yoga Lifestyles and the Traditional Texts}

Clearly these ideas about food and diet in AOL, Tiwari, Chopra and Plumb are validated through both explicit and implicit references to the traditional texts. For example, the concept of the three dosas, is derived from the classical texts on āyurveda. Not only is āyurveda referred to as the oldest medical system in the world, but it is suggested that its roots lie in the Vedic period. Desai (personal interview, April 2014) observes that ayyurveda can be identified in the Vedas, particularly the $R g$ Veda and the

9 Having worked as a chef, the atmosphere in the AOL kitchens are very serene and calm in comparison to the professional kitchens that I worked in.

10 This will give a total of seven body types: vāta is dominant; pitta is dominant; kapha is dominant; vāta and kapha dominate; vāta and pitta dominate; pitta and kapha dominate; vāta, pitta and kapha are naturally in balance. 
Atharva Veda. Plumb (2018, p. 4) states that 'Ayurveda arose during the Vedic Sarasvati culture that flourished in the Western Himalayan plains from around 7000 BCE to about 1900 BCE.' It is not clear where Plumb derives these dates from. Although there is a considerable debate about the dates of the Vedic culture, the earliest portion of the Vedas is generally thought to be composed from about 1500 BCE (Witzel 2005, p. 68). However, the actual dates are not important, what is significant is that the assertion of the ancient roots of the ayyurvedic diet validates its authenticity. This idea of ancient roots provides a sense of stability in a world that is often perceived in terms of constant flux.

Plumb (2018, p. 36) also suggests, like Field and Frawley mentioned above, that 'Ayurveda is the sister science of Yoga. Thus the first principle of Yoga, ahimsa ... is an important principle in Ayurveda too.' We have seen that the concept of ahimsā, which is frequently cited to support vegetarianism can be found in PYS. The AOL (2018e) website states, 'The ancient treatise of Patanjali Yoga Sutra speaks of the concept of 'Ahimsa' (non-violence), as one of the core values of yoga' and is therefore an important argument for not eating meat. Plumb (2018, p. x) refers to the Caraka Samhitā, which she cites as indicating, 'The distinction between health and disease arises as the result of the difference between wholesome and unwholesome diet.' In other words, these ideas do not emerge from a vacuum but are represented as part of an ancient tradition. Chopra is less explicit about the sources of his ideas and tends to be more reliant on a quasi-scientific idiom scattered with New Age maxims to support his claims about a healthy diet.

I suggest that while modern yoga and āyurveda, refer to the classical texts and ancient traditions, there are some differences. The conception of modern yoga is contentious. Modern yoga is very diverse and by no means homogenous However, I agree with Elizabeth De Michelis (2004) who argues that there are distinctive forms of 'modern yoga,' which can be distinguished from more traditional forms of yoga.

Modern yoga is a technical term used to refer to certain types of yoga that evolved mainly through the interactions of Western individuals interested in Indian religions and a number of more or less Westernized Indians over the past 150 years. (De Michelis 2004, p. 2)

Traditional yoga is also very diverse, and as Mallinson and Singleton (2017, p. xi) observe 'traditional yoga rarely, if ever, occurs outside of particular religious and doctrinal contexts.' Traditional yoga can also be divided between the more philosophical, found in texts such as PYS, and the more physical styles of yoga practice, commonly referred to as hathayoga (the Yoga of Force) found in texts such as HYP. This text is again very difficult to date, but most commentators suggest that it was compiled from much earlier material in the fifteenth century CE. The HYP contains some instructions about postures (āsana) and breathing exercises (prānāyama) commonly associated with yoga as a physical exercise. A tradition arose in which both philosophical aspects and the physical training were taught alongside each other, and 'by the eighteenth century hatha and Pātañjala yoga were seen as one and the same' (Mallinson and Singleton 2017, pp. xx-xxi).

While there are no direct references to food in PYS, the HYP does indicate what foods the yogi should consume and what foods should be avoided. For example, the HYP (Sinh 1914, p. 23) suggests avoiding over eating and to 'be moderate in diet.' The yogi is informed to avoid fish, meat, garlic ${ }^{11}$ and onion, but wheat, rice, some vegetables, honey, mung dhal are beneficial (Sinh 1914, p. 48). Interestingly the HYP indicates that ghee is beneficial. Plumb $(2018$, p. 58) also suggests that ghee has positive properties, and (Tiwari 1995, p. 182) observes that 'ghee is one of the most ancient and sattvic foods.' Nonetheless, the recipes in both Tiwari and Plumb use comparatively little ghee or oil in comparison to most other modern cookbooks. As we have seen AOL suggests that an āyurvedic diet should use fats and oils very sparingly, and recommends steaming, rather than frying, as a method of

11 In many of the āyurvedic texts garlic is regarded as having medicinal properties. There is a wonderful section on garlic in a collection of āyurvedic texts known as the Bower Manuscript (see Wujastyk 2003, pp. 154-60). For example, garlic 'drives away pallid skin disease, appetite-loss, abdominal lumps, coughs, thinness, leprosy and weak digestion' (p. 160). 
cookery. Unsurprisingly Chopra's book, which has a focus on weight loss, uses fats and oils sparingly. Clearly adjustments have been made in the light of current nutritional understanding that high levels of fat are responsible for a range of diseases and conditions associated with modern diets.

While modern yoga and new age àyurveda are authenticated through an appeal to an ancient and traditional past, frequently making references to Patañjali, they also draw upon Western ideas of individuality This suggests that the āyurvedic diet can be tailored to individual needs, through determining one's own particular body type. This is consistent with what Heelas (2008, p. 28) has called 'inner-life spiritualties' which are 'bound up with the theme of transforming the unique life of the person' (emphasis in original). Plumb (2018, p. 7) suggests 'Ayurveda is enlivening because it gives you permission to be wholly and uniquely you (my emphasis).

Modern forms of yoga and āyurveda are primarily concerned with therapeutics, which Lasch (1979, p. 2) suggests is 'a hunger not for personal salvation ... but for the feeling, a momentary illusion, of personal wellbeing, health, and psychic security.' Health and wellbeing are common tropes in many contemporary books about yoga/āyurveda and food. For example, Grabau (2014) publication The Yoga of Food has the subtitle: Wellness from the Inside Out. Healing the Relationship with Food and Your Body.

Many forms of modern yoga, such as AOL have become a lifestyle choice which often focus on wellbeing, health and psychic security. Tiwari $(1995$, p. 8) describes āyurveda as 'a philosophy of living' and Plumb (2018, p. 5) suggests that āyurveda involves 'positive lifestyle changes.' These modern forms of yoga and modern àyurveda cookbooks can be clearly identified with lifestyles of health and sustainability-sometimes simply referred to by the acronym LOHAS-which in 2003 the New York Times indicated might be 'the biggest market you have never heard of' (Emerich 2012, p. 40). Balance and harmony are common tropes in LOHAS discourse. Therefore, it is considered that proper lifestyle choices have the potential to restore balance and harmony in our lives, and this particularly applies to our food choices. As sattva is commonly translated as balance and harmony, it is readily appropriated in LOHAS discourses. For example, in a recent article in the Yoga Journal O'Donnell (2018) published an article on 'How a Sattvic Diet Brings You Into Balance,' and Maya Tiwari's popular book is called Ayurveda: A Life of Balance.

We live in an age that has many anxieties around food. There is a concern that food has become over-elaborated and industrially produced, and therefore not only removed from nature, but also perceived as a direct threat to both individual and environmental health. Modern foodways are often linked to moral panics about health and the destruction of the natural environment, and consequently many people seek healthier alternatives, both for themselves and for the planet. Fast food in particular has become a metonym for the pace, imbalance and anxieties of modernity. We have sped away from our true selves in all that we do. What we eat and how we eat has come to represent our alienation from others, the natural world and ourselves, which the anthropologist Claude Fischler has described as 'gastro-anomie' (Caplan 1997, p. 5). Yoga perceived as a means to lead a healthy, holistic and sustainable lifestyle inevitably involves ideas about proper diet.

Modern yoga is articulated in terms of a range of techniques that can establish a harmony between body, mind and spirit, that can make us feel good about ourselves-physically, psychologically and spiritually-in an age of anxiety. It is hardly surprising that if one of the most significant anxieties of the contemporary age revolves around what and what not to eat, that there is a growing interest in what the yogic traditions have to say about food and diet. While we do find yoga classes being offered in gyms and leisure centres simply as a form of physical exercise, many people involved in contemporary yoga movements perceive yoga as a lifestyle. Chaney (1996) suggests that lifestyles have three characteristics. First, lifestyles are 'patterns of action that differentiate people' (Chaney 1996, p. 4). Second, lifestyles are determined by what Chaney $(1996$, p. 3) terms 'a sensibility,' which he defines as 'a way of responding to events or actions or phenomena that has a certain pattern of coherence.' Finally, lifestyles can be perceived as 'functional responses to modernity' (Chaney 1996, 
p. 11). Modern yoga, despite its diversity, can be perceived as a coherent pattern of action which functions as a response to the perceived anomie of modernity.

The three most widely sold yoga magazines in the UK-Om Yoga, Yoga Magazine and Yoga Journal —all can be considered as lifestyle publications. As well as information about various yoga poses, these magazines have interviews with various yoga teachers, articles about yoga and beauty, suggestions for yoga vacations in exotic locations and so on. Om Yoga explicitly indicates that it is a lifestyle magazine, 'It's not just about doing yoga, it's about living yoga.' All of these popular publications have a section on food, and recipes for dishes that are regarded as being commensurate with the yogic lifestyle. The December 2014 edition of Om Yoga not only has recipes for vegetarian 'Festive Feasts,' but also a short article about yogic diet-indicating that it should be 'vegetarian, fresh, simple, unprocessed and nutritious' (Williamson 2014, p. 130). O'Donnell (2018) in her article in Yoga Journal suggests that 'eating can be a companion to your yoga practice and may help you pay attention to how foods make you feel—not just in your gut, but in your heart—and how they can affect your mood.' Consequently, one could understand a yogic diet as a distinctive foodway-'a set of beliefs and practices that govern consumption' (Dallam 2014, p. xviii). Modern yoga, as exemplified by groups such as AOL, as the name implies, is regarded as a lifestyle choice that has implications for many aspects of daily life, most noticeably decisions about what to eat and to avoid eating.

Increasing numbers of people involved in various types of yoga around the world seek diets that they consider apposite to the modern yogic lifestyle. Although, as I have indicated, prohibitions and prescriptions around diet that can be found in the classic yoga texts, modern yogis tend to refer to àyurveda - the ancient Indian system of medicine - for advice about what to eat and what to avoid.

Some aspects of traditional āyurveda seem to be consistent with the therapeutic ideas of the holistic mileu. Caraka suggests:

Food is the vital breath of living beings and that is why people rush to food. Complexion, cheerfulness, good voice, life, imagination, happiness, contentment, strength, intellect-all these are dependent on food. (Caraka Saṃhitā Su 27: 349 in Van Loon 2002, p. 228)

This conception of food is consistent with what Heelas (2008, p. 52) calls wellbeing spirituality. Consequently, ayyurvedic ideas are readily appropriated by those seeking a holistic and healthy lifestyle. These ideas are authenticated not only through the appeal to an ancient wisdom that is represented as being more natural than modern lifestyles, but also because it directly appeals to the experiential aspect of therapeutic culture-or as Rieff $(1966$, p. 22) so eloquently expresses it 'the I believe of the ascetic' (or in our case the yogi) has 'lost precedence to 'one feels' the caveat of the therapeutic.' One active member of AOL observes that from personal experience when she attends AOL courses 'I feel the benefit of having a fairly strict āyurvedic diet' (personal interview, April 2014).

\section{Conclusions}

Many modern forms of yoga, such as AOL, can be located in the holistic milieu which emphasise health and wellbeing for mind, body and spirit. What to eat and what not to eat are regarded as significant aspects of the modern yogic lifestyle. Balance and harmony are important tropes in the holistic milieu and are often articulated with ideas about food and diet. In the philosophy of Yoga the term sattva-one of the three qualities of nature-is often translated as balance, and therefore seems congruent with the ethos of modern yoga and the holistic milieu. By extension, it is suggested that a sattvic diet plays a crucial therapeutic role in keeping mind, body and soul in balance. Anita Desai suggested that, 'Sattvic food is food which is light, rich in life-force, should purify people and restore the balance between mind, body and spirit' (personal interview, April 2014).

Âyurveda, the ancient system of Indian medicine, is also viewed as an appropriate resource for the holistic milieu. Zysk (2001, p. 13) identifies what he calls 'New Age Āyurveda,' which defines health in holistic terms and as a positive state of being, rather than simply curing of disease, which resonates with therapeutic discourses on wellbeing in the holistic milieu. Wujastyk and Smith (2008, p. 11) note 
that 'ayurveda has increasingly identified itself as a kind of preventative medicine; indeed, it has become as much a positive lifestyle index as a system for curing illness.' As Sri Sri Ravi Shankar expresses it, 'Health is not the mere absence of disease. Health is the dynamic expression of life' (AOL 2015b).

While yoga and āyurveda have some commonalities, they are distinctive traditions. However, with the focus on the therapeutic aspects of both traditions in the modern context, they are increasingly conflated in the mind, body spirit discourses of the holistic milieu. This conflation is particularly apparent in discourses about food where sattva, a complex yogic concept, is articulated with ideas about an āyuyrvedic diet.

It is now well established, especially in the holistic milieu, that correct diet has a significant role to play in maintaining health and wellbeing. An AOL blog suggests:

The benefits of Ayurvedic cooking are plentiful and contribute to overall health and wellness.

They include better mood control, freedom from depression and anxiety, and increased energy levels. (AOL Retreat Centre 2018)

Modern yoga and modern āyurveda, as therapeutic practices, are primarily validated through personal experience of well-being. However, while the experiential can be regarded as necessary validation for therapeutic practices, including food choices, it is often regarded as being insufficient. Modern yoga and āyurveda are also authenticated through identifying them with a reimagined tradition and selective references to ancient concepts and traditional texts. In particular the sattvic diet-a diet of balance and harmony-is traced back to the ancient Vedic past. Charles Lindholm (2008, p. 25) suggests that discourses of authenticity tend to be either historical/genealogical or romantic/expressive. In the historical/genealogical discourse authenticity is articulated with the past, whereas the romantic/expressive discourse views authenticity in terms of personal emotions or experience. The sattvic diet, as suggested in AOL and by writers such as Maya Tiwari and Laura Plumb, is validated both historically and romantically.

Many in the holistic milieu are also suspicious of tradition, which is often associated with external authority, and/or superstition. Consequently, there is frequently mistrust of institutions, and in particular institutionalised forms of religion (see Sutcliffe and Sælid 2013). Holistic practices must be represented as not only associated with an authentic tradition but must also be seen as rational. Consequently, the sattvic diet is also represented as rational and scientific, and is often articulated with ideas of modern nutrition, such as avoiding high fat diets. The sattvic diet is also specified in terms of food being fresh, local and organic, which is consistent with the holistic critique of fast and industrialised food production. Consequently, AOL's authentication of a sattvic diet is itself a balance between the three qualities of experience, tradition and reason.

Funding: This research received no external funding.

Conflicts of Interest: The author declares no conflict of interest.

\section{References}

Alter, Joseph. 2004. Yoga in Modern India. Princeton: Princeton University Press.

Anānda in the Himalayas. 2018. Dining and Cuisine. Available online: http:/ / www.anandaspa.com/dining.html (accessed on 7 May 2018).

AOL. 2015a. Sneak Preview into the Art of Living Kitchen in Bengaluru. Available online: https://www.youtube. com/watch?v=KJq68be0h50 (accessed on 3 September 2018).

AOL. 2015b. Sri Sri Tattva Panchakarma. Available online: https:/ /www.youtube.com /watch?time_continue=2\& v=HYG9ZDZxxD0 (accessed on 3 September 2018).

AOL. 2018a. Ayurveda. Available online: https://www.artofliving.org/uk-en/ayurveda (accessed on 7 May 2018).

AOL. 2018b. Food. Available online: http:/ / www.artofliving.org/food (accessed on 7 May 2018). 
AOL. 2018c. Ayurveda Cooking. Available online: http://www.artofliving.org/node/93698 (accessed on 7 May 2018).

AOL. 2018d. What Is Ayurveda. Available online: https://www.artofliving.org/ayurveda (accessed on 4 December 2018).

AOL. 2018e. Why the Wise Go Veg with Yoga. Available online: https:/ /www.artofliving.org/yoga/yoga-andfood/Going-vegetarian (accessed on 4 September 2018).

AOL Retreat Centre. 2018. How Food Can Be Your Medicine with Ayurveda. Available online: https:/ / artoflivingretreatcenter.org/blog/how-food-can-be-your-medicine-with-ayurveda (accessed on 4 December 2018).

BBC. 2018. Vegetarian and Vegan: A Quarter of UK Dinners Have No Meat or Fish. Available online: https: / / www.bbc.co.uk/news/uk-42973870 (accessed on 4 September 2018).

Caplan, Pat. 1997. Approaches to the Study of Food, Health and Identity. In Food, Health and Identity. Edited by Pat Caplan. London: Routledge, pp. 1-31.

Chaney, David. 1996. Lifestyles. London: Routledge.

Chopra, Deepak. 2014. What Are You Hungry For? London: Rider.

Collingham, Lizzie. 2005. Curry: A Biography. London: Chatto and Windus.

Dallam, Marie W. 2014. Introduction: Religious Foodways. In Religion, Food and Eating in North America. Edited by Benjamin E. Zeller, Marie W. Dallam, Reid L. Neilson and Nora L. Rubel. New York: Columbia University Press, pp. xvii-xxxiii.

De Michelis, Elizabeth. 2004. A History of Modern Yoga. London: Continuum.

De Michelis, Elizabeth. 2008. Modern Yoga: History and Forms. In Yoga in the Modern World: Contemporary Perspectives. Edited by Mark Singleton and Jean Byrne. London: Routledge, pp. 17-35.

Desai, Kaushani. 2010. Sattva: The Ayurvedic Cookbook. Bangalore: Sri Sri Publications.

Eliade, Mircea. 1989. Yoga: Immortality and Freedom. London: Arkana.

Emerich, Monica M. 2012. The Spirit of Living Slowly in the LOHAS Marketplace. In Religion, Media and Culture: A Reader. Edited by Gordon Lynch and Jolyon Mitchell. London: Routledge, pp. 40-48.

Field, Gregory. 2001. Religious Therapeutics: Body and Health in Yoga, Āyurveda and Tantra. Albany: State University of New York Press.

Frawley, David. 1999. Yoga and Ayurveda: Self-Healing and Self-Realization. Twin Lakes: Lotus Press.

Grabau, Melissa. 2014. The Yoga of Food: Wellness from the Inside Out. Healing the Relationship with Food and Your Body. Woodbury: Llewellyn Publications.

Heelas, Paul. 2008. Spiritualities of Life: New Age Romanticism and Consumptive Capitalism. Oxford: Blackwell.

ISKCON. 2014. How to Eat Healthy. Available online: http:/ / www.iskcon.org/how-to-eat-healthy (accessed on 4 September 2018).

Johnson, W. J. 1994. The Bhagavad Gita. Oxford: Oxford University Press.

Jacobs, Stephen. 2014. Inner Peace and Global Harmony: Individual Wellbeing and Global Solutions in the Art of Living. Culture Unbound 6: 873-89. [CrossRef]

Jacobs, Stephen. 2015. The Art of Living Foundation: Spirituality and Wellbeing in the Global Context. Farnham: Ashgate. Lasch, Christopher. 1979. The Culture of Narcissism. New York: W. W. Norton.

Lindholm, Charles. 2008. Culture and Authenticity. Oxford: Blackwell.

Mallinson, James, and Mark Singleton. 2017. Roots of Yoga. London: Penguin.

Morningstar, Amadea. 1995. Ayurvedic Cooking for Westerners. Twin Lakes: Lotus Press.

O’Donnell, Kate. 2018. How a Sattvic (Pure) Diet Brings You Into Balance. Yoga Journal. June 7. Available online: https:/ / www.yogajournal.com/lifestyle/how-a-sattvic-pure-diet-brings-you-tobalance\# gid=ci02283ee5700026c2\&pid=food_302_kitchari_bjk (accessed on 4 September 2018).

Plumb, Laura. 2018. Ayurveda Cooking for Beginners: An Ayurvedic Cookbook to Balance and Heal. Emeryville: Rockbridge Press.

Rieff, Philip. 1966. The Triumph of the Therapeutic. Harmondsworth: Penguin.

Rosen, Steven J., ed. 2011. Food for the Soul: Vegetarianism and Yoga Traditions. Santa Barbara: Praeger.

Sinh, Pancham. 1914. Hatha Yoga Pradīpikā. Available online: https://archive.org/details/ HathaYogaPradipikaPanchamSinghOCR (accessed on 7 May 2018).

Sondhi, Amrita. 2006. The Modern Ayurvedic Cookbook: Healthful Healing Recipes for Life. Vancouver: Arsenal Pulp Press. 
Sri Sri Ravi Shankar. 1992. Vegetarianism Audio. Available online: http:/ /www.artoflivingshop.eu/index.php/site/ products/product/vegetarianism-only-for-download-acden0009,827,1,2 (accessed on 10 December 2014).

Sri Sri Ravi Shankar. 2012. Sri Sri Ravi Shankar Discusses Healthy Eating and Living. Andaaz. Available online: https: / / www.youtube.com/watch?v=J2ph1XzJQe0 (accessed on 1 September 2018).

Sutcliffe, Steven J., and Gilhus Ingvild Sælid. 2013. New Age Spirituality: Rethinking Religion. Durham: Acumen.

Tiwari, Maya. 1995. Ayurveda: A Life of Balance. Rochester: Healing Arts Press.

Van Loon, Gabriel, ed. 2002. Charaka Samhita: Handbook on Ayurveda Volume 1. Available online: https: / / ayurvedika.ru/forum/misc.php?action=pun_attachment\&item=113...1 (accessed on 7 May 2018).

Whicher, Ian. 1998. The Integrity of the Yoga Darśana. Albany: State University of New York Press.

Williamson, Lexie. 2014. Don't Get Stuffed. Om Yoga, November 20.

Witzel, Michael. 2005. Vedas and Upaniṣads. In The Blackwell Companion to Hinduism. Edited by Gavin Flood. Oxford: Blackwell, pp. 68-101.

Wujastyk, Dominik. 2003. The Roots of Ayurveda. London: Penguin.

Wujastyk, Dagmar, and Frederick M. Smith, eds. 2008. Modern and Global Ayurveda: Pluralism and Paradigms. Albany: State University of New York Press.

Yarema, Thomas, Daniel Rhoda, and Johnny Branningan. 2006. Eat, Taste, Heal: An Ayurvedic Cookbook for Modern Living. New York: Five Elements Press.

Zysk, Kenneth. 2001. New Age Āyurveda: Or What Happens to Indian Medicine When It Comes to America. Traditional South Asian Medicine 6: 10-26.

(C) 2018 by the author. Licensee MDPI, Basel, Switzerland. This article is an open access article distributed under the terms and conditions of the Creative Commons Attribution (CC BY) license (http:/ / creativecommons.org/licenses/by/4.0/). 